\title{
Economics
}

\section{Asset Ownership by Women in Urban and Rural South West Nigeria}

\author{
Yetunde Olasimbo Mary Oladokun \\ Department of Agricultural Economics, University of Ibadan, Ibadan City, Nigeria \\ Email address: \\ yetunde.oladokun@gmail.com

\section{To cite this article:} \\ Yetunde Olasimbo Mary Oladokun. Asset Ownership by Women in Urban and Rural South West Nigeria. Economics. \\ Vol. 9, No. 2, 2020, pp. 21-26. doi: 10.11648/j.eco.20200902.11
}

Received: February 6, 2020; Accepted: February 25, 2020; Published: May 29, 2020

\begin{abstract}
In improving the welfare of women asset ownership plays a key role. Therefore this paper examined asset ownership by women in urban and rural South West (SW) Nigeria. Secondary data from Demographic and Health Survey 2013 was used. Data on 1551 rural and 4323 urban women in SW Nigeria was used. Information on their socio-economic characteristics and assets (physical and natural) was obtained. Data analysis was done using descriptive statistics, multiple correspondence analysis and probit regression. In rural and urban South West the mean age was 30 years. The mean household size in rural and urban SW was 6 and 5 persons respectively. Mobile telephone has a proportionally far higher weight (0. 043, $0.050)$ and radio too $(0.037,0.042)$ than the remaining assets in rural and urban SW. From the probit regression nine variables were found to be statistically significant at various levels in both rural and urban South West. The significant variables in rural SW were age (25-34) (-0.30), age 35-49 (0.51), employed in agric and allied sector (0.17), incomplete secondary school education (-0.14), complete secondary school education $(-0.16)$, higher education $(0.84)$, being a female household head $(0.17)$, marital status-married (0.63). In the urban SW the variables that are significant are age-35-49 (-0.32), skilled and unskilled employment (0.13), employed in agric. and allied sector (-0.50), employed in the services sector (0.10), incomplete secondary education (0.24), complete secondary education (0.28), household sized 6-10 persons $(-0.12),>10$ persons household size $(-0.23)$. Conceited efforts should therefore be put in place by women agencies to enact policies that will help women to own more assets.
\end{abstract}

Keywords: Asset Ownership, Rural, Urban, South West, Women

\section{Introduction}

Assets may be intangible in form of social capital, skills and knowledge or tangible in form of equipment, farmland, livestock and dwellings [1]. Assets could also be productive/non-productive assets. Productive assets such as human capital (time, skills), natural (land, livestock, water, and forest), financial capital and fixed capital are those that are used as inputs in the production process. On the other hand, non-productive assets yield income through transfers or capital gains when assets are liquidated. [2] stated that the two categories of assets offer a source of income and a store of wealth. Assets helps to generate livelihoods and buffer the effect of common disasters of diseases, flooding and drought that affect many African countries [3]. Assets can also be distinguished based on ownership and can be solely held by persons and collectively held without access restrictions.

[4] revealed that the poor in Nigeria, majority of whom are women and rural based, are usually confronted with lack of assets. Women in the rural areas tend to have less assets than women in the urban areas because they lack access to amenities like electricity, good road network and effective communication through mobile phones. Access and ownership of productive assets have positive impact on the welfare of women and their household [5, 6]. According to [7] the ownership of assets can provide important sources of income for women and facilitate access to credit, enabling investments into education and other productive assets. Assets strengthen women's ability to cope with and respond to economic shock as a store of wealth [8]. There has been a great focus on asset ownership at household level, this disallow analysis in asset ownership between men and women. Important development outcomes including household food security and human capital formation have been positively influenced by women's asset holdings [9]. Hence, facilitating women in gaining more access to productive assets would 
help them to improve their well- being and that of their household. In this paper asset ownership among women in rural and urban South West Nigeria was examined. Factors influencing the ownership of assets in rural and urban South West was also determined. This paper is in line with the Sustainable Development goals (SDGs) which is to promote gender equity (Goal 5) and ending poverty in all forms (Goal 1). This would enable government and non-government organizations come up with policies to help women in the accumulation of assets.

\section{Methodology}

The study area for this research is South West Nigeria. This is one of the geopolitical zones in Nigeria. It comprises of six states namely Lagos, Ogun, Oyo, Osun, Ondo and Ekiti. The major language in this zone is Yoruba with many local dialects even within each state. There are majorly two distinct seasons in Nigeria; the dry season (November - February) and the rainy season (March - November) [10]. Secondary data from [11] was used for this study. The sample for Demographic and Health Survey 2013 was a stratified sample. From the sampling frame the sample was selected independently in three stages and each state was separated into urban and rural areas. Four thousand three hundred and twenty three (4323) women in urban and One thousand five hundred and fifty one (1551) women in rural SW were interviewed. The total data of 4323 and 1551 women in rural and urban South West were used for analysis.

The analytical techniques used for this study are descriptive statistics, Multiple Correspondence Analysis (MCA) and Probit regression.

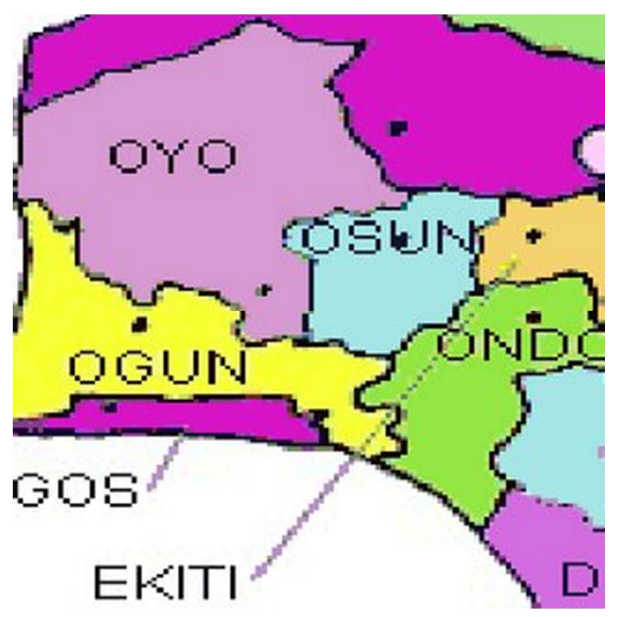

Source: https://www.researchgate.net

Figure 1. Map showing the states in South West.

Multiple Correspondence Analysis (MCA)

MCA was used to assess the asset ownership by generating the asset indices for women. MCA is similar to principal components analysis or factor analysis. According to [12] the only difference is that MCA is suitable for categorical variables. Thus, MCA is suitable for this study as most variables are categorical. In simple terms, aj represents the weight of class $j$ and $R i j$ the classification of woman $i$ to class $j$, then the asset index score of a woman $i$ is:

$$
\mathrm{MCA}_{\mathrm{i}}=\sum_{j=1}^{j} a j R i j
$$

This index can then be normalized between 0 and 1 to allow for inter temporal and cross region comparisons by the following formula

$$
\text { normalised_MCAi }=\frac{M C A i-\min (M C A)}{\max (M C A)-\min (M C A)}
$$

The assets to be considered include Physical and Natural [11].

\section{Probit regression}

The explanatory variables used in this model were selected from literature. These include women's socio-economic characteristics and household characteristics. The relationship between the probability of owning assets or not, $\mathrm{Pi}$, and its determinants, $\mathrm{xi}$, is given as:

$$
\mathrm{P}_{\mathrm{i}}=\beta \mathrm{x}_{\mathrm{i}}+\mu_{\mathrm{i}} \text { where } \mathrm{Pi}=1 \text { for } \mathrm{x}_{\mathrm{i}} \geq \mathrm{z}
$$

$\mathrm{i}=1,2 \ldots \ldots, \mathrm{n}$.

Pi: asset index cutoff $(1=$ asset index above mean, $0=$ asset index below mean).

$\mathrm{x}_{1}=15-24$ years (yes $=1,0$ otherwise), $\mathrm{x}_{2}=25-34$ years (yes $=1,0$ otherwise), $x_{3}=35-49$ years (yes $=1,0$ otherwise), $x_{4=}$ unemployed (yes $=1,0$ otherwise), $\mathrm{x}_{5}=$ unskilled manual employment type (yes $=1,0$ otherwise), $\mathrm{x}_{6}=$ skilled manual employment type (yes $=1,0$ otherwise), $x_{7}=$ agriculture employment type (yes $=1,0$ otherwise), $\mathrm{x}_{8}=$ services employment type (yes $=1,0$ otherwise), $\mathrm{x}_{9}=$ No formal education (yes $=1,0$ otherwise), $\mathrm{x}_{10}=$ incomplete primary education (yes $=1,0$ otherwise),

$\mathrm{x}_{11}=$ primary education (yes $=1,0$ otherwise), $\mathrm{x}_{12}=$ incomplete secondary education (yes $=1,0$ otherwise), $\mathrm{x}_{13}$ $=$ complete secondary education (yes $=1,0$ otherwise), $\mathrm{x}_{14}=$ tertiary education (yes $=1,0$ otherwise), $\mathrm{x}_{15}=$ sex of household head (male $=1,0$ otherwise), $x_{16}=$ sex of household head (female $=1,0$ otherwise), $x_{17}=$ single (yes $=1,0$ otherwise), $\mathrm{x}_{18}=\operatorname{married}(\mathrm{yes}=1,0$ otherwise)

\section{Results and Discussion}

Socio-Economic Characteristics of Women in South West

In Table 1, 35.7\% of women are within 35-49 years closely followed by women within $25-34$ years $(34.6 \%)$ in rural SW, while in the urban area $33.6 \%$ of women are within $15-24$ years and between 25-34 years. There are older women in rural area compared to the urban area. This could be because younger women in the urban areas attend colleges and universities and are involved in white collar jobs. The mean age of women is 30 years in the study areas. Twenty four percent of women in rural South West have incomplete secondary education while a higher percentage has complete secondary $(35.8 \%)$ in the urban area. In SW, women in the urban areas are more educated. Women in rural SW have a mean household size of 6 with mean household size of 5 for women in urban SW. Women in urban areas have small 
household size because they may have white collar jobs and may not have enough time to take care of many children. On the other hand, in rural areas women can afford to have medium to large household size since their households need farm labour and they can also carry their children to the farm to work. Women in urban and rural SW are married $(64.8 \%$ and $62.7 \%$ ). Women in the South West are mostly employed in the service sector $(47.1 \%$ and $61.3 \%)$

Table 1. Socio economic Characteristics of women.

\begin{tabular}{|c|c|c|c|c|}
\hline \multirow{2}{*}{ Variable } & \multicolumn{2}{|l|}{ Rural } & \multicolumn{2}{|l|}{ Urban } \\
\hline & Frequency & Percentage & Frequency & Percentage \\
\hline \multicolumn{5}{|l|}{ Age } \\
\hline $15-24$ & 536 & 34.6 & 1454 & 33.6 \\
\hline $25-34$ & 461 & 29.7 & 1441 & 33.3 \\
\hline $35-49$ & 544 & 35.7 & 1428 & 33.0 \\
\hline Mean & 30 & & 30 & \\
\hline \multicolumn{5}{|l|}{ Educational attainment } \\
\hline No education & 334 & 21.5 & 161 & 3.7 \\
\hline Incomplete primary school education & 86 & 5.5 & 107 & 2.5 \\
\hline Complete primary school education & 317 & 20.4 & 582 & 13.5 \\
\hline Incomplete secondary school education & 375 & 24.2 & 990 & 22.9 \\
\hline Complete secondary school education & 331 & 21.3 & 1549 & 35.8 \\
\hline Tertiary education & 108 & 7.0 & 934 & 21.6 \\
\hline \multicolumn{5}{|l|}{ Household size } \\
\hline $1-5$ & 879 & 56.7 & 2839 & 56.7 \\
\hline $6-10$ & 582 & 37.5 & 1394 & 37.5 \\
\hline$>10$ & 90 & 5.8 & 90 & 5.8 \\
\hline Mean & 6 & & 5 & \\
\hline \multicolumn{5}{|l|}{ Marital status } \\
\hline Single & 578 & 37.3 & 1523 & 35.2 \\
\hline Married & 973 & 62.7 & 2800 & 64.8 \\
\hline \multicolumn{5}{|l|}{ Occupation type } \\
\hline Unemployed & 397 & 25.6 & 1202 & 27.8 \\
\hline Skilled and unskilled & 122 & 7.9 & 401 & 9.3 \\
\hline Agric and allied & 302 & 19.5 & 72 & 1.7 \\
\hline Services & 730 & 47.1 & 2648 & 61.3 \\
\hline
\end{tabular}

Source: Author's computation 2013 DHS data

\section{Profile of asset ownership}

In Table 2, Majority (81.5\% and 94.8\%) of women in South West own mobile telephone. It is the most owned asset in the study area. Seventy and eighty percent of women in urban and rural SW had radio ownership, $84.2 \%$ of women in urban south west owned television making it to be the second most owned asset, urban women can assess information through this unlike women in the rural women where only $4.3 \%$ own television. Hence, television ownership has implications for their wellbeing and that of their household. Most of the women in the rural SW do not own assets such as generating set, refrigerator, electric iron, fan. More women in urban SW owned productive assets like generating set and refrigerator; ownership of these assets could improve their welfare and help their businesses. The ownership of productive assets by women in the study area could boost peace of mind and high mental development, good health thus making life comfortable.

Also as revealed in table 2, 7.7\%, 36.6\%, 24.8\%, owned car/truck, motorcycle/scooter and bicycle, respectively in rural SW while in urban SW more women own car/truck which is the most preferred means of transportation in this group. The ownership of these assets are low probably because of the high cost of purchase or poor road network. Fast and timely delivery of rural products especially the perishable products are made possible through good transportation thereby improving profitability and income of women.

In Table 3 women do not own land in rural and urban SW, $82.9 \%$ and $86.0 \%$ while $83.4 \%$ and $89.7 \%$ do not own house. In Africa culture women are not allowed to own land. Land ownership is of utmost importance as it can be of great importance to women especially during difficult times [13].

Table 2. Distribution of Asset ownership in rural and urban South West.

\begin{tabular}{lllll}
\hline \multirow{2}{*}{ Assets } & Rural & \multicolumn{3}{l}{ Urban } \\
\cline { 2 - 5 } & Freq. & \% & Freq. & Percent \\
\hline Radio & 1082 & 69.7 & 3472 & 80.3 \\
Television & 749 & 4.3 & 3639 & 84.2 \\
Bicycle & 67 & 24.8 & 116 & 2.7 \\
Motorcycle/scooter & 567 & 36.6 & 973 & 22.5 \\
Mobile telephone & 1264 & 81.5 & 4099 & 94.8 \\
Watch & 924 & 59.6 & 3582 & 82.9 \\
Fan & 647 & 41.7 & 647 & 41.7 \\
Electric iron & 477 & 30.8 & 477 & 30.8 \\
Animal drawn cart & 2 & 0.1 & 10 & 0.2 \\
Boat with a motor & 14 & 0.9 & 2 & 0.1 \\
Generating set & 390 & 25.2 & 1843 & 42.6 \\
Canoe & 96 & 6.2 & 7 & 0.2 \\
Computer & 31 & 2.0 & 437 & 10.1 \\
Air conditioner & 5 & 0.3 & 208 & 4.8 \\
Cable Television & 59 & 3.8 & 748 & 17.3 \\
Car/ truck & 119 & 7.67 & 824 & 19.1 \\
Refrigerator & 186 & 11.99 & 1722 & 39.8 \\
\hline
\end{tabular}

Source: Author's computation 2013 DHS data 
Table 3. Land and House Ownership.

\begin{tabular}{lllll}
\hline \multirow{2}{*}{ Land Ownership } & Rural & \multicolumn{3}{c}{ Urban } \\
\cline { 2 - 5 } & Freq. & $\mathbf{\%}$ & Freq. & \% \\
\hline Does not own & 1286 & 82.9 & 3716 & 86.0 \\
Own Alone & 68 & 4.4 & 168 & 3.9 \\
Own Jointly & 163 & 10.5 & 387 & 9.0 \\
Alone and Jointly & 34 & 2.2 & 52 & 1.2 \\
House Ownership & & & & \\
Does not own & 1293 & 83.4 & 3876 & 89.7 \\
Own Alone & 42 & 2.7 & 88 & 2.0 \\
Own Jointly & 181 & 11.7 & 318 & 7.4 \\
Alone and Jointly & 35 & 2.26 & 41 & 1.0 \\
\hline
\end{tabular}

Source: Author's computation 2013 DHS data

\section{Asset Ownership Using MCA}

The asset ownership by women was assessed using Multiple Correspondence analysis. Table 4 show the weights assigned to each asset. Mobile telephone has a proportionally far higher weight $(0.043,0.050)$ and radio $(0.037,0.042)$ than the remaining, indicative of the fact that the prevalence of mobile phone and radio ownership is very high in rural and urban SW. Mobile telephone has a proportionally far higher weight $(0.36)$ than house indicative of the fact that the prevalence of house ownership is very low. Also comparing the weight of mobile phone with land, computer, air condition shows that the ownership of these assets is low. Animal drawn cart, canoe, boat with motor have very low weight, this could be because they are specific to a place (for example riverine areas).

The total MCA value for the assets each woman owned was generated and the total asset index was determined. The mean of this index is 0.75 and 0.78 in rural and urban south west respectively. Therefore any woman that has a value below the mean is asset deprived. $43.52 \%$ and $42.82 \%$ has a value below the mean and thus do not have enough assets while $56.48 \%$ and $57.18 \%$ have enough assets. These women have assets generally but the assets they own are not productive and not enough to better their lives.

Table 4. Distribution of Asset Index by women in rural and urban SW.

\begin{tabular}{lll}
\hline \multirow{2}{*}{ Category } & Rural & Urban \\
\cline { 2 - 3 } & Asset index & Asset index \\
\hline Radio & 0.037 & 0.042 \\
Televisiono & 0.025 & 0.044 \\
Bicycle & 0.002 & 0.001 \\
Motorcycle & 0.019 & 0.012 \\
Land & 0.009 & 0.007 \\
House & 0.009 & 0.005 \\
Mobile telephone & 0.043 & 0.050 \\
Watch & 0.031 & 0.044 \\
Fan & 0.022 & 0.046 \\
Generating set & 0.013 & 0.030 \\
Canoe & 0.003 & 0.000 \\
Electric Iron & 0.016 & 0.039 \\
Computer & 0.001 & 0.005 \\
Air condition & 0.000 & 0.003 \\
Cable TV & 0.002 & 0.009 \\
Boat with motor & 0.000 & 0.010 \\
Car/Truck & 0.004 & 0.032 \\
Refrigerator & 0.006 & 0.030 \\
\hline
\end{tabular}

Source: Author's computation 2013 DHS data
Determinants of Asset Ownership in Rural and Urban South West

The determinants of asset ownership by women in rural and urban south west was examined using Probit model. The result showed that the chi-square value of 92.35 and 171.02 in rural and urban SW is statistically significant $(\mathrm{P}<0.01)$ which implies that the model has a good fit. The intercept of 0.6279 and 0.1480 are significant $(\mathrm{P}<0.05)$. Out of the twenty three variables hypothesized as determinants of asset ownership by women; only eight were found to be statistically significant at various levels in both rural and urban south west. The significant variables in rural SW were age (25-34) (-0.30), age 35-49 (0.51), employed in agric and allied sector (0.17), incomplete secondary school education (-0.14), complete secondary school education (-0.16), higher education (0.84), female household head (0.17), marital status-married (0.63). In the urban the variables that are significant are age-35-49 (-0.32), skilled and unskilled employment (0.13), employed in agric. and allied sector (-0.50), employed in the services sector $(0.10)$, incomplete secondary education (0.24), complete secondary education (0.28), household sized 6-10 (-0.12), >10 household size $(-0.23)$.

In line with a priori expectation, all the significant variables had the expected signs that depict the effect they had on asset ownership. The significant variables in urban south west were age 35-49 (-0.32), employed in skilled and unskilled (0.13), agric. and allied sector (-0.50), service sector (0.10), educational attainment incomplete secondary (0.24), complete secondary education (0.28), household size 6-10 (-0.11), greater $10(-0.23)$.

In urban south west the age of women (35-49) was negatively related to asset ownership and statistically significant at $1 \%$ which implies that as the age of women increases; the tendency for them to own more assets reduces.

The coefficients of women in skilled and unskilled was positive and significant at $10 \%$. Women involved in this type of employment have higher probability of owning more assets compared to their counterparts who are unemployed.

The coefficient of women in agric. and allied sector is negative and significant at 5\%. Women involved with this type of employment have a lower probability of owning assets compared to women who are unemployed.

The educational attainment of women (incomplete secondary, complete secondary) is positive and significant at $5 \%$ and $1 \%$ respectively, implying that completion of secondary school education is important for women in urban south west in owning assets.

The coefficient of household size (6-10 persons and $>10$ persons) was negative and significant at $1 \%$ and $10 \%$ respectively. This implies that women in medium/large households have a lower probability of owning assets as compared to women with small household size. In urban areas women are involved with jobs that are time demanding and thus they have less time for their families. Thus this may form their decision on having small households.

In rural South west the coefficients for women aged 35-49 years was positively related to asset ownership and statistically significant at $1 \%$. This shows that as the age of 
women increases their asset ownership increases. In rural areas as women get older they have more bargaining power and social capital [14]. This could help in asset accumulation.

Agriculture and allied employment type was positively significant at $10 \%$. This means that the asset ownership increased with increase in the number of women engaged in agriculture and allied when compared to women that are unemployed. Agriculture is a major sector that people in the rural areas are involved with. Women in this sector have discovered ways to thrive in this sector and this also aid their asset ownership.

The educational attainment of incomplete secondary and complete secondary school are negative while higher education was positive. In rural South West women need to have a higher education to own more assets. Women who are married have a positive coefficient and it was significant at $10 \%$. Women who are married tend to own more assets compared to women who are single.

Table 5. Factors influencing asset ownership in rural and urban South West.

\begin{tabular}{|c|c|c|c|c|}
\hline \multirow{2}{*}{ Predictor variables } & \multicolumn{2}{|l|}{ Rural } & \multicolumn{2}{|l|}{ Urban } \\
\hline & Coefficients & standard error & coefficients & standard error \\
\hline \multicolumn{5}{|l|}{ Individual level factors } \\
\hline Age (b: $15-24$ years) $25-34$ years & $-0.3002 * *$ & 0.1062 & 0.0043 & 0.0639 \\
\hline $35-49$ years & $0.5102 * * *$ & 0.1133 & $-0.3176 * * *$ & 0.0707 \\
\hline Employment (b: unemployed) Skilled and Unskilled & -0.1540 & 0.1457 & $0.1341^{*}$ & 0.0806 \\
\hline Agric. and allied & $0.1656^{*}$ & 0.1275 & $-0.5008^{* *}$ & 0.1669 \\
\hline Services & 0.1212 & 0.1086 & $0.1001 *$ & 0.0570 \\
\hline Complete primary & -0.0170 & 0.1021 & 0.1568 & 0.1130 \\
\hline Incomplete secondary & $-0.1378^{*}$ & 0.1067 & $0.2408 * *$ & 0.1109 \\
\hline Complete secondary & $-0.1634 *$ & 0.1072 & $0.2849 * * *$ & 0.1068 \\
\hline Higher & $0.8379 * * *$ & 0.1554 & -0.1696 & 0.1099 \\
\hline Sex of household head (b: Male) Female & $0.1667 *$ & 0.1245 & -0.0271 & 0.0697 \\
\hline Size of household (b: 1-5) 6-10 & -0.0432 & 0.0735 & $-0.1145 * * *$ & 0.0450 \\
\hline$>10$ & -0.1899 & 0.1496 & $-0.2301^{*}$ & 0.1424 \\
\hline Log likelihood & -1015.8341 & & -2866.2071 & \\
\hline Chi square & 92.35 & & 171.02 & \\
\hline Probability & 0.0000 & & 0.0000 & \\
\hline
\end{tabular}

$* * * \mathrm{P}<0.01$ significant at $1 \%, * * \mathrm{P}<0.05$ significant at $5 \%, * \mathrm{P}<0.1$ significant at $1 \%$

Source: Author's computation, 2013 DHS data b: base category

Physical and natural assets are the asset dimension considered in this study. Asset ownership is a means to reduce hunger and acute poverty which is the first SDG goal. [15] suggests considering asset ownership as a means to facilitating gender equality perspectives addressed by the third SDG. [16] opined that the ownership of physical assets can cause a decline in the probability of being monetarily poor. Assets are useful for smoothing consumption especially in developing countries where the poor often experience income volatility [17]. Therefore assets are likely to capture more closely the permanent part of consumption for households or individuals [18]. Thus a lack of assets could be considered to be a good substitute for chronic poverty [19].

In theory, analyzing the ownership of assets is an important way to explore inequality issues among household members. [20] stated that women's bargaining power within the household may be related to their possession of assets. In African countries, most surveys revealed that the possession of durable goods is not assigned individually but often credited to the whole family.

\section{Conclusion}

It is evidenced from this paper that women in rural south west do no own enough assets needed for their improved welfare compared to their urban counterparts. Based on the outcome of the study, asset ownership especially productive assets among rural women should be encouraged by government and non-governmental organisations. Women that own assets could be better than others in the provision of basic needs and through investments in future generations such as health care, education, and training, while those lacking assets are prone to poverty, shocks and disasters.

Government should also put in place policies to encourage women not only to have access to these assets but to own them and in implementing these policies the men should be carried along. Educational facilities should be provided in rural south west and girls should be encouraged to go to school because education was one of the key factors affecting asset ownership in urban SW.

\section{References}

[1] World Bank. 2003. World Development Report 2003: Sustainable Development in a Dynamic World. Washington DC: World Bank.

[2] Barrett, C. B. and Reardon, T. 2000. Asset, activity, and income diversifications among African agriculturalist: Some practical issues. Retrieved April 28, 2009 from http://papers.ssrn.com/sol3/papers.cfm?abstract_id $=257$ 344. 
[3] McPeak J. 2000. Analyzing and Addressing Localized Degradation in the Commons, Mimeo, Department of Agricultural Research and Managerial Economics, Cornel University, Ithaca, NY.

[4] World Bank 2001. World Development Report 2000/2001Attacking Poverty (New York: Oxford University Press).

[5] Johnson, N., Njuki, J., Waithanji, E., Nhambeto, M., Rogers, M. and Kruger, E. H. 2013. The gendered impacts of agricultural asset transfer projects: Lessons from the Manica Smallholder Dairy Development Program. CAPRI Working Paper No. 115. Washington, DC: International Food Policy Research Institute. http://dx.doi.org/10.2499/CAPRiWP115.

[6] Oladokun Yetunde Olasimbo Mary and Adenegan Kemisola Omorinre (2019). Asset Ownership and Welfare Deprivation of Women in rural Nigeria: A bi-causal relationship. Journal of Economics, Management and Trade, 23 (1): 1-16. www.journaljemt.com > index.php > JEMT > article > download.

[7] Massaquoi Y. 2014. Gender Equality, Human Rights and Environmental Integrity in the New Climate Agreement and Post-2015 Development Agenda. Prepared for the 3rd UNITAR-Yale Conference on Environmental Governance and Democracy, 5-7 September 2014, New Haven, USA.

[8] Goh, A. H. 2012. A literature review of the gender-differentiated impacts of climate change on women's and men's assets and well-being in developing countries. CAPRi Working Paper No. 106. Washington, D. C.: International Food Policy Research Institute.

[9] FAO (Food and Agriculture Organization of the United Nations). 2011. The state of food and agriculture 2010 2011: Women in agriculture: Closing the gender gap for development. Rome: FAO.

[10] https://www.myguidenigeria.com/regionalinfo/southwes $\mathrm{t}$ region.
[11] DHS, 2013. Nigeria Demographic and Health Survey.

[12] Booysen, F., Van Der Berg, S., Burger, R., Von Maltitz, M. and Du Rand, G. 2008. 'Assigning an asset index to Assess trends in poverty in seven Sub-Saharan African countries. World Development 36 (6): 1113-1130.

[13] Oladokun Y. O. M (2018): Asset Ownership and Welfare Deprivation of Women in Rural Nigeria. Unpublished $\mathrm{PhD}$ Thesis. Department of Agricultural Economics. University of Ibadan. xiii, $157 \mathrm{pp}$.

[14] Doss C. (2013). Intrahousehold bargaining and Allocation in developing countries. The world Bank research Observer 28 (1): 52-78.

[15] Sackey, H. A. 2005. "Poverty in Ghana from an assets- based perspective: an application of probit technique", African Development Review, 17.1: 41-69.

[16] OECD, 2010. "Gender inequality and the MDGs: what are the missing dimensions? OECD, Paris, September. https://www.oecd.org/dev/development-gender/45987065.pdf

[17] Brandolini, A., Magri, S. and T. M. Smeeding 2010. "Asset Based Measurement of Poverty," Journal of Policy Analysis and Management, 36: 1113-1130.

[18] Stifel, D. and L. Christiaensen 2007. "Tracking Poverty Over Time in the Absence of Comparable Consumption Data," The World Bank Economic Review, 21: 317-341.

[19] McKay, A. 2009. "Assets and chronic poverty: Background paper", Working Paper No. 100, Chronic Poverty Research Centre, Falmer.

[20] Deere, C. D., Alvarado, G. E. and Twyman, J. 2010. Poverty, Headship, and Gender Inequality in Asset Ownership in Latin America. Gender, Development, and Globalization Program Center for Gender in Global Context Michigan State University. Working paper 296. 